\title{
IDENTIFICAÇÃO DAS ÁREAS VERDES NO DISTRITO DA BARRA FUNDA, PARA A PROPOSTA DO PARQUE LINEAR BRÁS-LAPA E SUA CONTRIBUI- ÇÃO PARA UMA INFRAESTRUTURA VERDE NA CIDADE DE SÃO PAULO
}

\author{
Neila Custódio* e Ursula Brinker** \\ * Arquiteta e urbanista formada pela Universidade Braz Cubas. Trabalha no Metrô, na área de Projeto \\ com Paisagismo e Urbanização - ncustodio@metrosp.com.br. \\ ** Arquiteta e urbanista formada pela Universidade Federal da Bahia - ursula.brinker@gmail.com.
}

\begin{abstract}
RESUMO
A partir da proposta da disciplina de Projeto Sustentável para um Parque Linear BrásLapa, analisamos o distrito da Barra Funda (município de São Paulo), sua formação histórica, e a proposta do Plano Diretor Estratégico Regional da Lapa (PDER). Levantamos as áreas verdes existentes e sua relação com os aspectos de microclima/ ilha de calor da localidade, assim como a importância dos usos do distrito hoje e suas tendências. Descrevemos os benefícios da vegetação urbana, especificamente a arborização viária, para o ecossistema dessa região. A partir das análises, levantamos algumas hipóteses, alterando a configuração de algumas ruas importantes, como forma de agregar valor ao distrito da Barra Funda, por meio do desenvolvimento de um plano para uma infraestrutura verde interligando corredores, e caminhos verdes ligando ao parque proposto.
\end{abstract}

Palavras-chave: Parque Linear Brás-Lapa, ilha de calor, microclima, áreas verdes. 


\title{
IDENTIFICATION OF GREEN AREAS AT BARRA FUNDA DISTRICT FOR THE PROPOSAL OF LINEAR PARK BRÁS-LAPA AND ITS CONTRIBUTION TO GRE- EN INFRASTRUCTURE IN THE CITY OF SÃO PAULO
}

\begin{abstract}
Starting with the proposal of the subject Sustainable Design for a Linear Park BrásLapa, it is analyzed the district of Barra Funda (City of São Paulo), its historical formation and the proposed "Lapa Regional Strategic Plan" (PDER). It was searched the existing green areas and its relationship to aspects of microclimate/local heat island as well as the importance of the current uses of the district and its trends. It is described the benefits of urban vegetation, specifically the street tree program for the ecosystem of that region. From such analyzes it was considered some hypothesis by changing the configuration of some important streets as a way to add value to the district of Barra Funda by developing a green infrastructure plan connecting corridors and green pathways linking the proposed park.
\end{abstract}

Key words: Linear Park Brás-Lapa, Heat Island, Microclimate, Green Areas.

\section{INTRODUÇÃO}

O grupo da disciplina Projeto Sustentável propõe a criação de um parque linear denominado Brás-Lapa, a fim de trabalhar com a mobilidade urbana sustentável na cidade de São Paulo, exatamente na área da Operação Urbana Água Branca.

O estudo para o projeto do Parque Linear Brás-Lapa apresentará áreas e corredores verdes, conexão entre as áreas verdes e os equipamentos culturais e sociais relevantes, hierarquização do sistema viário, transporte público, potencial do uso do solo e readequação da via férrea - CPTM.

Como o Parque Linear Brás-Lapa conterá elementos estruturadores, como calçadas verdes, corredores verdes e ciclovias, entendemos que o resultado será de um parque que se torne uma infraestrutura verde significativa na paisagem urbana da cidade de São Paulo. Sua funcionalidade está atrelada, quando propomos uma rede de espaços interconectados, tratando as questões relacionadas ao manejo das águas urbanas, conforto ambiental, biodiversidade, alternativas de circulação, acessibilidade, imagem 
local e lazer, promovendo benefícios à sociedade.

Este artigo tem a finalidade de apontar como a modificação do perfil de algumas ruas, com equipamentos voltados para a mobilidade urbana e a distribuição de árvores, contribuirá para uma infraestrutura verde dentro de uma área que já se encontra bastante urbanizada, implicando significativamente no incremento da qualidade ambiental. Utilizando a infraestrutura verde, podemos, então, reconhecer e aproveitar os serviços que a natureza pode realizar no ambiente urbano.

\section{DISTRITO DA BARRA FUNDA}

Na segunda metade do século XIX, surge o transporte sobre trilhos em São Paulo, a estrada de ferro Sorocabana e a Santos - Jundiaí. As planícies, antes vazias, começaram a ser ocupadas, influenciando na formação de vários bairros, e não foi diferente com o bairro da Barra Funda.

O bairro caracterizou-se pelo uso misto - área industrial e de habitação operária -, tendo seu traçado permanecido o mesmo, desde seu início até hoje: um plano praticamente ortogonal de ruas, convergindo para a estrada de ferro, que corta o bairro ao meio. A divisão do bairro pela estrada de ferro é tão marcante, que cada uma de suas partes recebeu uma denominação: Barra Funda de Baixo ou Várzea da Barra Funda - área compreendida entre o Tietê e a via férrea, formando, com o Bom Retiro, quase que um corpo único -, e a Barra Funda de Cima, área entre a via férrea e um trecho antigo da Rua das Palmeiras, atual Avenida General Olímpio da Silveira.

A paisagem urbana começou a modificar-se nas áreas suburbanas, com uma diferenciação mais nítida entre zona fabril e residencial. Na Várzea da Barra Funda, as fábricas foram-se distribuindo de maneira mais esparsa, ocupando áreas maiores, sem a antiga concentração de habitação operária em seu entorno. A Barra Funda de Cima, mais influenciada pelos bairros de Santa Cecília, Perdizes e Campos Elísios, assistiu a um processo de expulsão de suas indústrias maiores, caracterizando-se como zona residencial para classe média, pequena indústria e oficina, conservando poucos traços físicos característicos de bairro operário italiano.

O bairro foi formado principalmente pelos italianos, responsáveis por boa parte do povoamento do bairro, na primeira metade do século XX. Os negros também tiveram 
sua importância na constituição de grande parte da população do bairro, residindo nos cortiços, cômodos ou porões das casas.

Em 1900, era inaugurada a primeira linha de bondes elétricos da Capital, unindo a Barra Funda ao centro da cidade. O bonde não influiu no tipo de formação do bairro, que já estava com seu traçado determinado. Seu trilho, porém, correndo em trechos das ruas Barra Funda e Brigadeiro Galvão, concentrou ao longo delas o principal comércio e os serviços do bairro.

Na década de 70, a verticalização começava lentamente a fazer parte da realidade desse bairro, com poucos edifícios de apartamentos. Seu perfil horizontal ainda é um contraste, na paisagem de uma região da cidade cercada pelos espigões dos bairros vizinhos. Os poucos prédios existentes formam uma paisagem estranha, dentro de um ambiente constituído principalmente por um comércio variado, porém pouco expressivo, e residências antigas e simples, com detalhes arquitetônicos entalhados no início do século XX. Os casarões antigos foram transformados em cortiços e vilas. As primeiras indústrias da cidade foram substituídas pelas oficinas e por pequenas e médias fábricas.

Em 1988 começa a construção do Terminal Intermodal da Barra Funda - o maior da cidade - do Rodoviário Oeste e, em 1989, é inaugurado o Memorial da América Latina, com projeto de Oscar Niemeyer.

O Plano Diretor Regional apresenta vários objetivos para o desenvolvimento urbano da região, porém aqui atentaremos especialmente para a qualidade ambiental. São eles:

1. Promover a preservação, recuperação e melhoria das condições de ocupação do solo, de forma a garantir o controle da permeabilidade, em especial na extensa planície aluvial;

2. Promover intensas e extensas ações para diminuir os graves problemas ambientais de drenagem, poluição atmosférica, sonora e de desconforto térmico, adotando planos e programas de gestão ambiental;

3. Viabilizar as transformações urbanísticas e ambientais, fazendo uso das operações urbanas consorciadas da Diagonal Norte Lapa/Vila Leopoldina/ Jaguaré, estabelecidas pelo PDE, bem como propor alterações na Lei $n^{\circ} .11 .774$, de 18 de maio de 1995, que dispõe sobre a Operação Água Branca. 
A Operação Urbana tem como propósito a reurbanização da orla da ferrovia, visando integrar as diretrizes da CPTM ao plano urbanístico; a recuperação da importância da ferrovia funcional e paisagística; a criação de novos eixos, incentivando o percurso do andar a pé, e facilitar acesso de automóveis, ônibus e pedestres às estações de trens e metrô.

Segundo o plano Diretor Regional da Subprefeitura da Lapa, a Operação Urbana Água Branca deve ser revista, visando a inclusão dos novos instrumentos de política urbana, definidos no PDE e no Estatuto da Cidade.

A Operação Urbana Água Branca hoje apresenta dados não mais consistentes, com relação à proposta para residência e uso comercial. Atualmente, a área apresenta uma defasagem na relação uso residencial e não residencial.

\section{RESUMO DOS ESTOQUES}

$\begin{array}{lll} & \text { Residencial } & \text { Não residencial } \\ \text { Limite de estoque } & 300.000,00 & 900.000,00 \\ \text { Consumo } & 184.288,38 & 233.897,09 \\ \text { Em análise } & 141.296,83 & 10.092,85 \\ \text { DISPONÍVEL } & 115.711,62 & 666.102,91\end{array}$

Fonte: site da prefeitura de São Paulo - Operação Urbana

Outra questão a ser avaliada pela Operação Urbana é a criação de uma avenida que substituiria o volume de carros hoje abrigado pelo Minhocão, que seria demolido.

Quando a Operação Urbana Água Branca fala da recuperação das referências paisagísticas, não deixa claro quais são essas referências. Aqui entendemos, como referências paisagísticas, elementos presentes na cidade que marquem o local, que deem identidade, ajudando a definir a qualidade da paisagem, para que haja interesse em seu uso. 


\section{IDENTIFICAÇÃO DAS ÁREAS VERDES DO DISTRITO DA BARRA FUNDA}

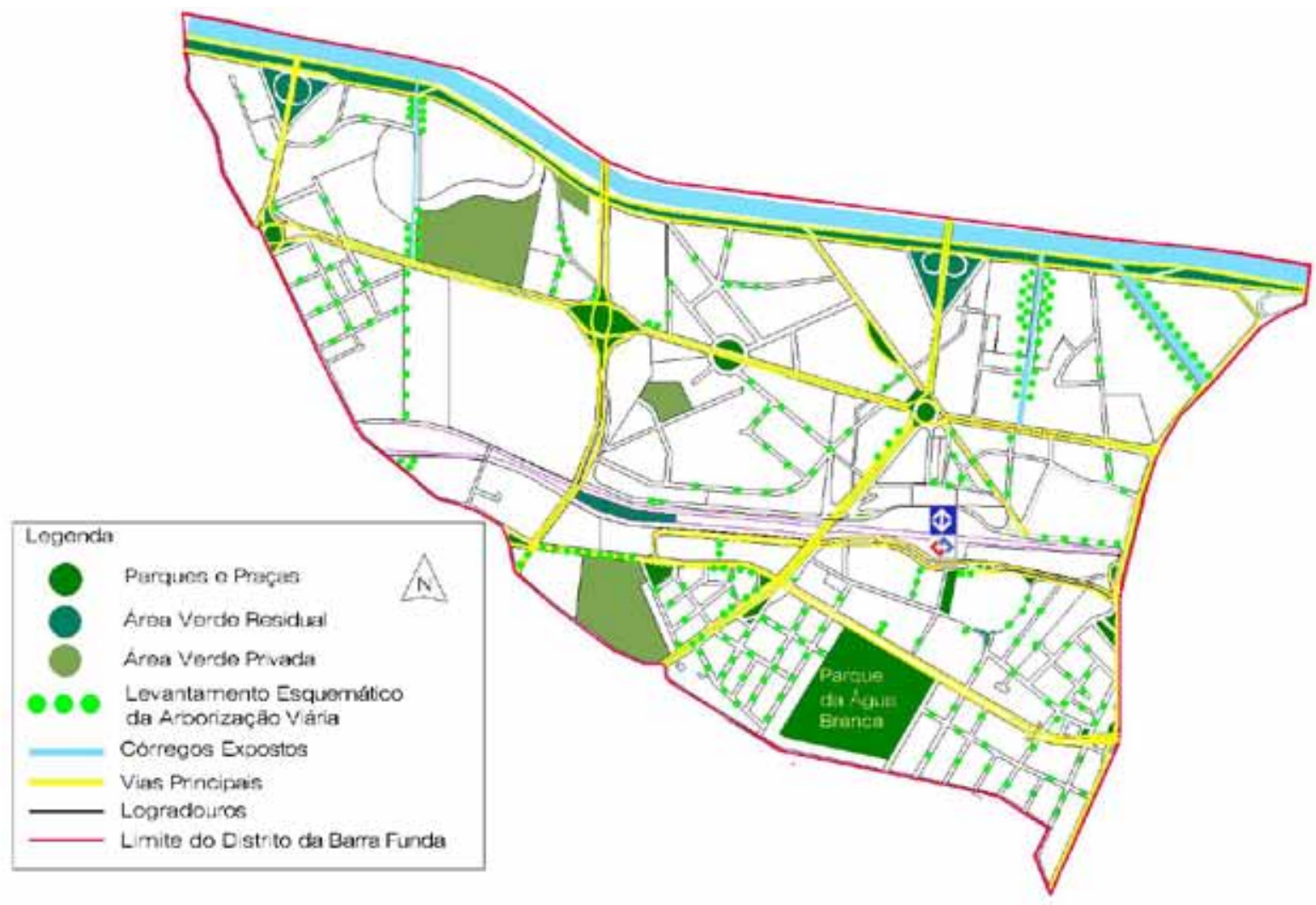

Mapa 1: Distrito da Barra Funda, com o levantamento das áreas verdes. Crédito: Ursula Brinker.

Ao observar o mapa acima, percebemos claramente a falta de áreas verdes na região. Entendemos aqui, como área verde, áreas permeáveis, pois na grande maioria não há arborização significativa. O que vemos de áreas verdes são, na sua maioria, áreas residuais do sistema viário, como rotatórias, alças de acessos, áreas residuais ladeadas pela linha férrea, algumas áreas privadas, como o São Paulo Futebol Clube, Clube Palmeiras, área livre próxima ao Circo dos Sonhos.

O que temos de mais significativo de área verde com arborização e equipamentos é o Parque da Água Branca e a Praça Conde Francisco Matarazzo Junior, em frente a casa das Caldeiras. Consideraremos, portanto, o Parque da Água Branca um núcleo verde, dada a sua importância como área verde pública, dentre a grande malha cinza urbana. Encontramos, também, um resquício de vegetação ciliar, nos córregos expostos Água Branca, Quirino dos Santos e Pacaembu.

Também encontramos algumas ruas arborizadas esparsamente na área residencial 
mais próxima ao Parque da Água Branca, subindo para Perdizes. Algumas ruas largas, na região da Barra Funda baixa - várzea -, apresentam algumas árvores já bem formadas. Com relação a grandes avenidas, somente um pequeno trecho da Av. Francisco Matarazzo, em frente ao Shopping Bourbon. Neste trecho, há de se observar que a identidade da avenida é diferenciada, há um acolhimento, aconchego, com um clima mais agradável, tanto visualmente, quanto com relação à temperatura, porém, quando passamos pelo Viaduto Pompeia, indo em direção ao Minhocão, tudo fica árido.

O resultado da escassez de áreas verdes na região em questão está exposto no mapa abaixo, referente à temperatura. Percebemos que estamos em uma região com temperaturas entre 29,5 e 31 graus, como demonstra o mapa abaixo.

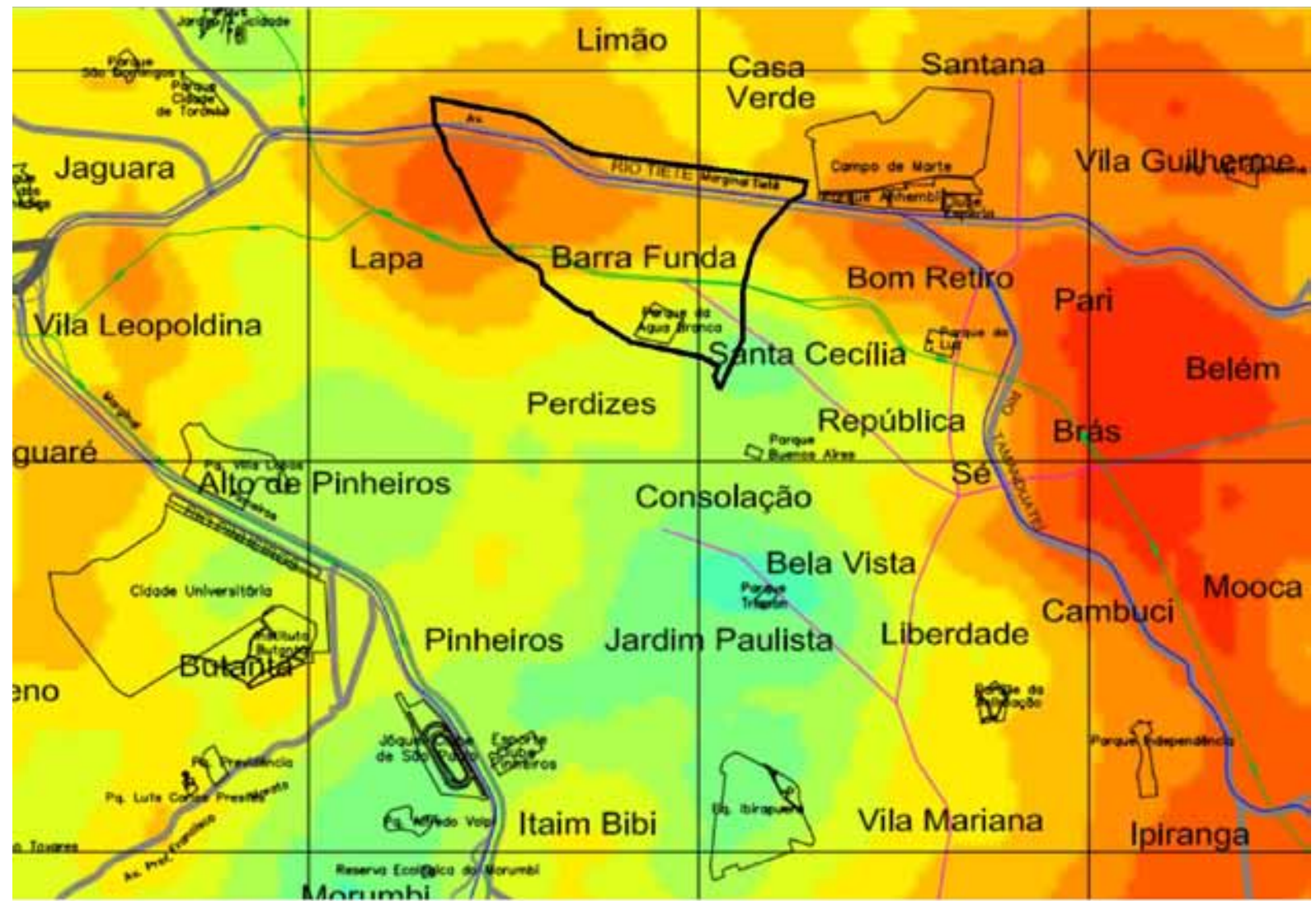

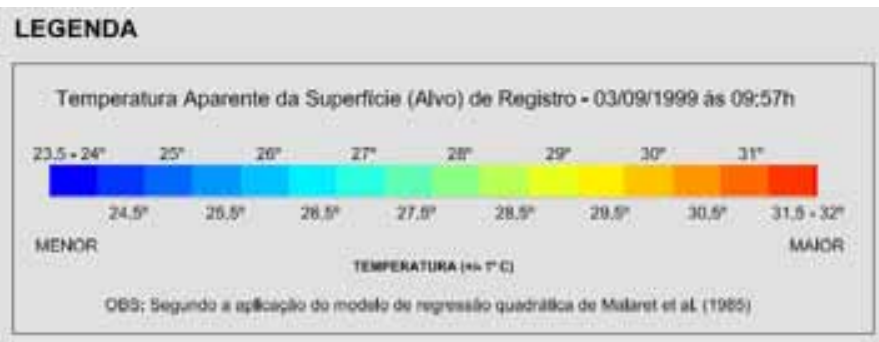

Figura 1: Temperatura do distrito da Barra Funda, comparado às demais áreas. Somente próximo ao Parque da Água Branca, em direção a Santa Cecília, começa a meIhorar a temperatura, estendendo-se para a Consolação, Bela Vista e Jardim Paulista. Fonte: Atlas Ambiental do Município de São Paulo - Temperatura da Superfície. 
Com a análise do mapa acima, percebemos que as áreas verdes são importantes no contexto urbano, podendo agir na regularização do clima local, com a redução das temperaturas e da poluição, aumento da drenagem, e, portanto, da qualidade de vida urbana.

\section{IDENTIFICAÇÃO DOS USOS NO DISTRITO DA BARRA FUNDA}

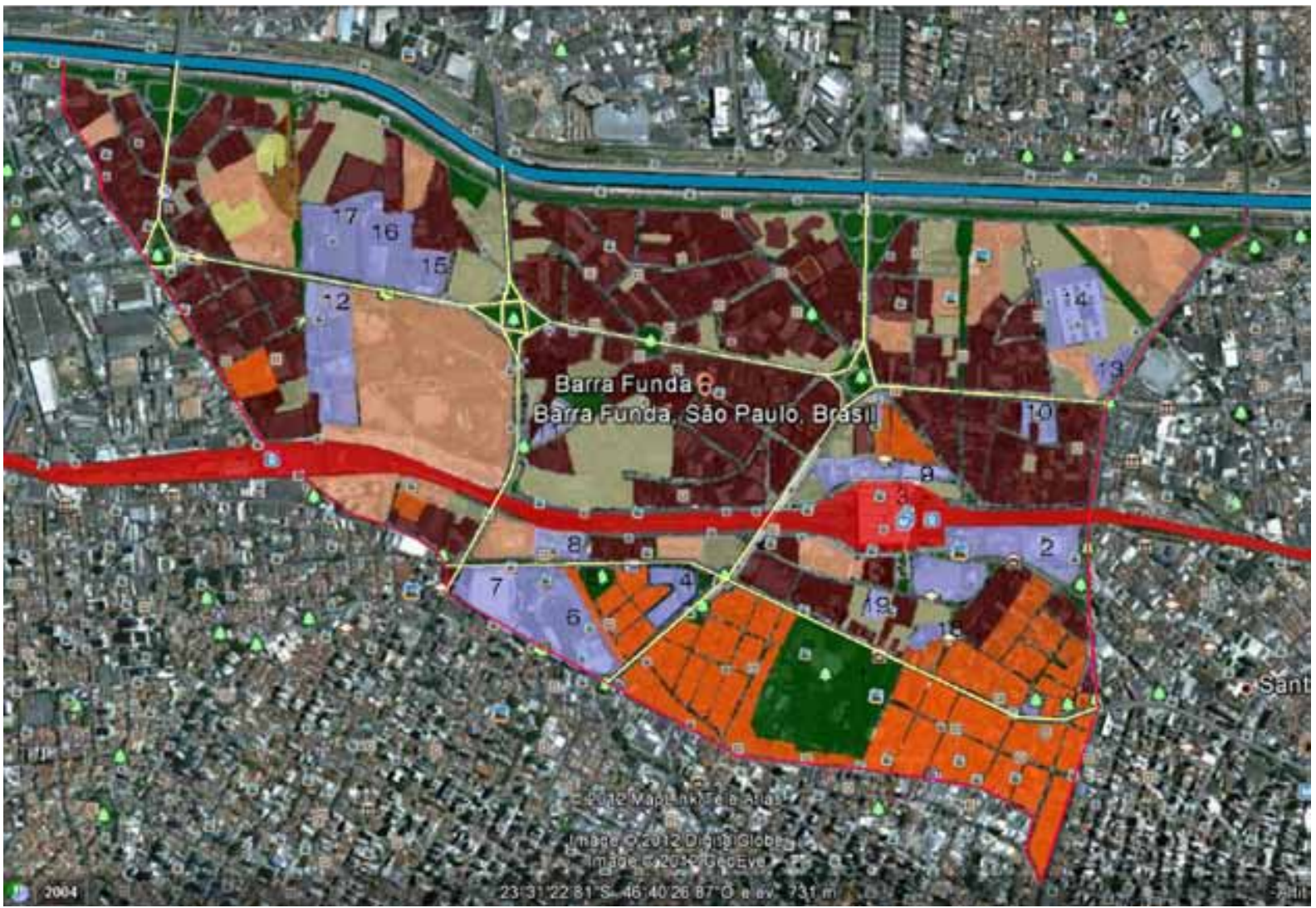

Mapa 2: Distrito da Barra Funda com a predominância dos usos. Crédito: Ursula Brinker.
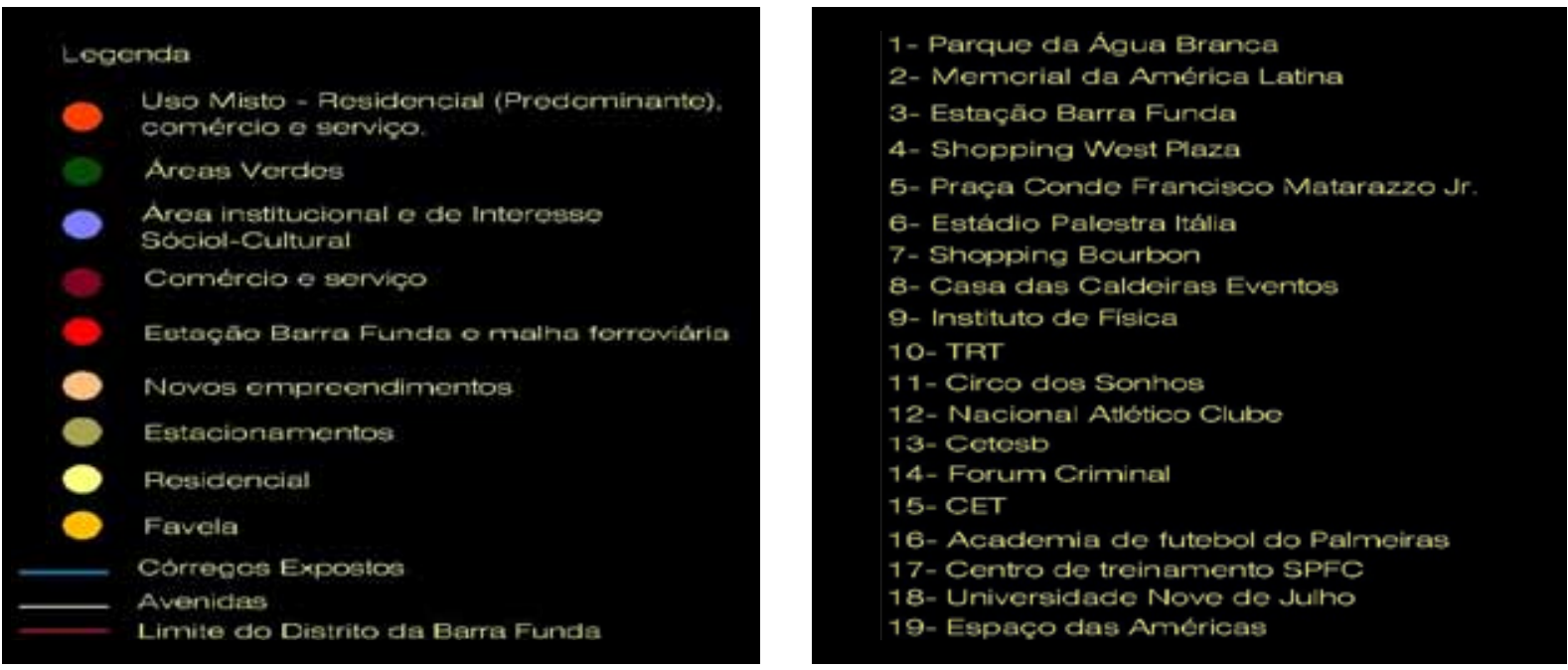
O distrito da Barra Funda apresenta muitas áreas subaproveitadas e impermeáveis, como grandes estacionamentos, que poderiam se tornar parques, formando áreas núcleos. Outra forma para trabalhar a permeabilidade e para a melhoria da ilha de calor na região seria a arborização urbana.

De acordo com Furlan (2004), a cidade poderia aumentar sua arborização por meio das estruturas viárias, porém um dos problemas são as múltiplas funções dadas às calçadas e aos canteiros centrais, apesar de a Prefeitura diagnosticar que seria um ganho na melhoria da qualidade ambiental dos bairros.

As intervenções associadas ao aumento dos espaços verdes melhorariam a qualidade ambiental dos lugares altamente adensados, ampliariam as áreas sombreadas, reduziriam a temperatura, elevariam o percentual da umidade relativa etc., pois, de acordo com Freitas e Lombardo (2007, p. 70), "[...] o planejamento urbano é um processo constante que permite diagnosticar os problemas locais visando promover o ordenamento racional, a avaliação da qualidade ambiental [...]'.

Para Mascaró (2010), as árvores, os arbustos e outras plantas menores e em seu conjunto constituem elementos da estrutura urbana. Caracterizam os espaços da cidade, por suas formas, cores e modo de agrupamento; são elementos de composição e de desenho urbano, ao contribuir para organizar, definir e até delimitar esses espaços. Desempenham funções importantes para o recinto urbano e para seus habitantes, ajudam no controle do clima e da poluição, na conservação da água, na redução da erosão e na economia de energia. Além disso, promovem a biodiversidade e o bem-estar dos habitantes, valorizam áreas, servem como complementação alimentícia e fonte de remédios para as populações carentes, embelezando seus deteriorados espaços de moradia.

\section{BENEFÍCIOS DA VEGETAÇÃO}

Entendemos que uma paisagem formada com vegetação em seus espaços públicos traz vários benefícios. Sob o ponto de vista dos aspectos ambientais, a vegetação atua nos microclimas urbanos, contribuindo para melhorar a ambiência urbana sob diversos aspectos: ameniza a radiação solar, diminuindo a temperatura e aumentando a umidade relativa do ar; modifica a velocidade e direção dos ventos; atua como barreira acústica; quando em grande quantidade, interfere na frequência das chuvas e, por meio da fotossíntese e da respiração, reduz a poluição do ar. 
Desta forma, apresentamos a seguir os aspectos importantes que dão suporte ao ecossistema do local onde será inserido o Parque Linear Brás-Lapa como infraestrutura verde, permitindo conexões através de corredores verdes, ruas mais arborizadas, ciclovias e passeios mais adequados.

\section{Valores qualitativos e quantitativos}

Os valores qualitativos estão relacionados com a criação das sensações estéticas e visuais, dando qualidade ao ambiente. Agrupamentos arbóreos homogêneos ou heterogêneos podem ter várias funções, como barreiras ambientais, definidores do espaço ou acontecimento espacial com função ornamental, como o alinhamento de palmeiras, que pode ressaltar a perspectiva ,ou sugerir imponência aos espaços, sem vedálos. Neste caso, as palmeiras não contribuem para amenização do clima. Já quando as copas de árvores se cruzam com efeito geométrico do plantio, o clima é minimizado, aumentando o sombreamento, que se dá com árvores de porte médio ou grande.

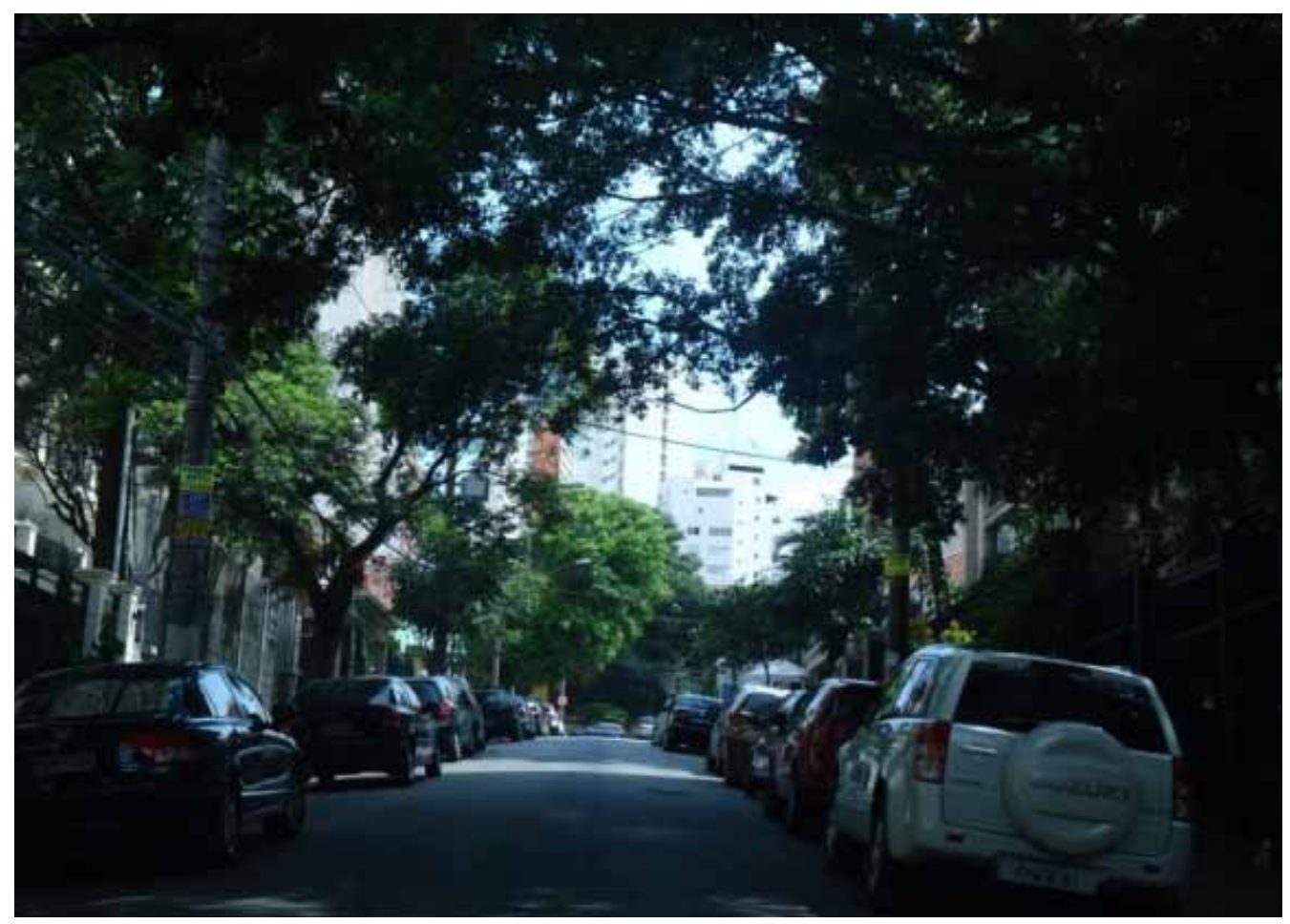

Foto 1: A Rua Lincoln Albuquerque é um dos poucos exemplos que temos, na área de estudo, com sombreamento de árvores que se cruzam. Esse sombreamento ocorre apenas em um quarteirão da rua. Essa rua está situada ao lado do Parque da Água Branca, em área residencial, onde inicia o bairro de Perdizes. Crédito: Neila Custódio. 
Os valores quantitativos tratam efetivamente não só da quantidade de áreas verdes, mas como essas são distribuídas, para que tragam benefícios climáticos. A quantidade de vegetação está intimamente ligada ao conforto térmico. As plantas possuem volumes com porte, forma, textura, cor, densidade de folhagem, floração, galharia e características ambientais, que variam de espécie para espécie. Árvores plantadas isoladas têm potencial para amenizar o desconforto do microclima urbano, porém seus efeitos de sombreamento, diminuição da temperatura e elevação da umidade relativa do ar só serão sentidos sob sua copa.

As imagens a seguir mostram a diferença entre propriedades privadas e calçadas não vegetadas com as vegetadas.

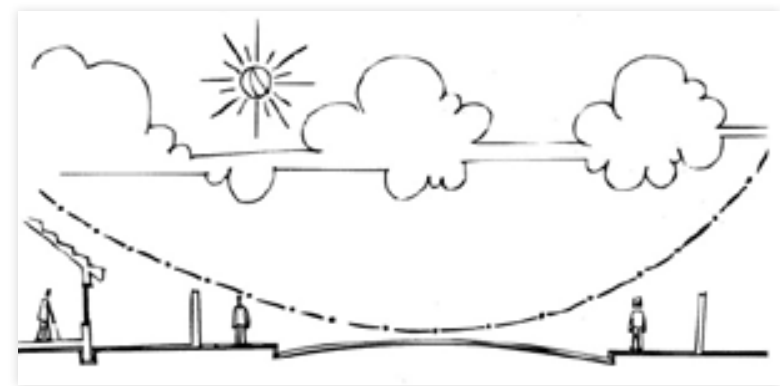

Figura 2: Rua sem vegetação, os muros estreitam seus espaços. Fonte: Mascaró, 2010.

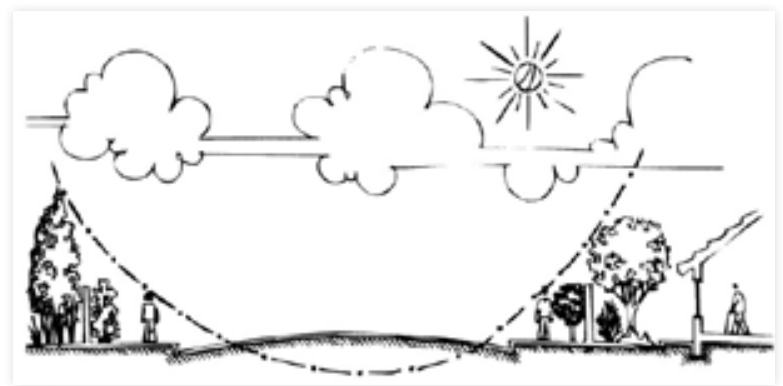

Figura 3: A vegetação protege o muro e amplia psicologicamente os espaços urbanos, melhorando sua ambiência. Fonte: Mascaró, 2010.

2. Aspectos climáticos - microclima e ilhas de calor

A função das árvores na cidade, quanto aos aspectos climáticos, é de remover partículas poluentes, por meio das aberturas dos estômatos, onde os gases poluentes são dissolvidos nos espaços intercelulares e podem ser absorvidos para gerar ácidos, ou reagir com as superfícies internas da folha. Assim, as árvores também removem temporariamente os poluentes, ao reter as partículas na superfície da folha, que podem entrar ou retornar à atmosfera, serem levadas pelas águas da chuva, ou ainda ficarem incorporadas ao solo, quando a folha se desprender.

Através da evapotranspiração - perda de água que ocorre pela evaporação da superfície do solo e pela transpiração estomática e cuticular das 
plantas -, podemos abaixar em até três graus a temperatura dos ambientes onde se insere a vegetação. Desta forma, a intervenção dos espaços propondo áreas vegetadas pode beneficiar quanto à intensidade e direção dos ventos, proteção ao ruído urbano, conforto térmico quanto ao sombreamento, e amenização do clima, diminuindo a ilha de calor.
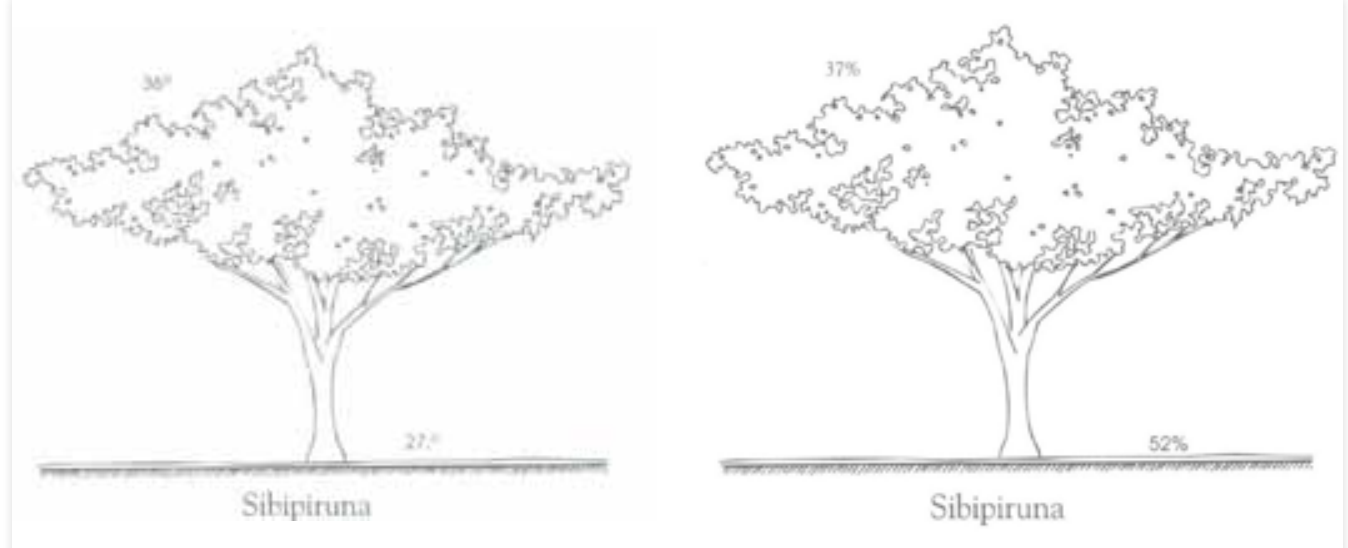

Figura 4: Redução da temperatura na sombra de uma sibipiruna, e alteração da umidade relativa do ar. Fonte: Mascaró, 2010.

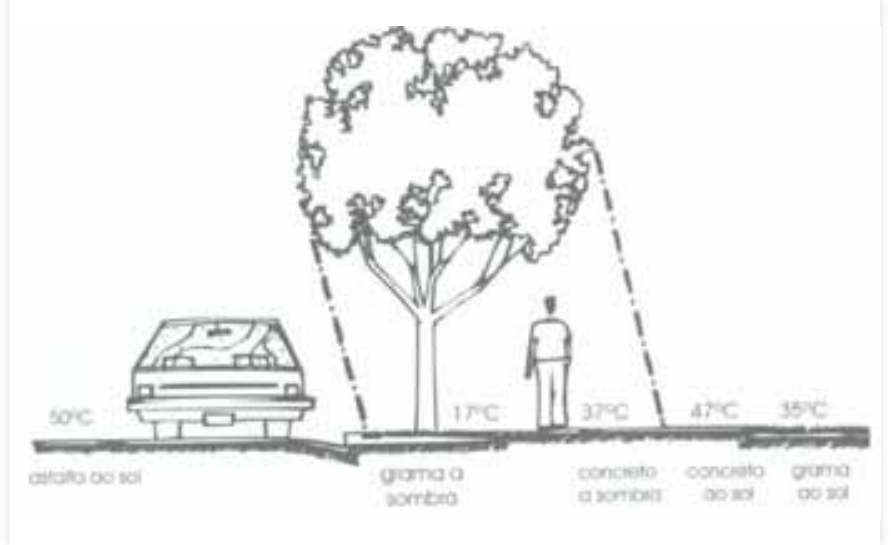

Figura 5: Ilustração mostrando a incidência solar em diferentes matérias. Fonte: Laurie, 1978.

3. Manejo de água e permeabilidade de piso

O tratamento dos espaços públicos com pisos permeáveis e calçadas mais amplas permite que possamos intervir na captação da água de chuva, por meio da criação de canteiros pluviais, biovaletas e jardins de chuva, contribuindo para a qualidade ambiental, quando filtram as águas da chuva, que podem ser reaproveitadas, e quando retêm as águas da chuva, não saturando o sistema de águas pluviais da cidade. 


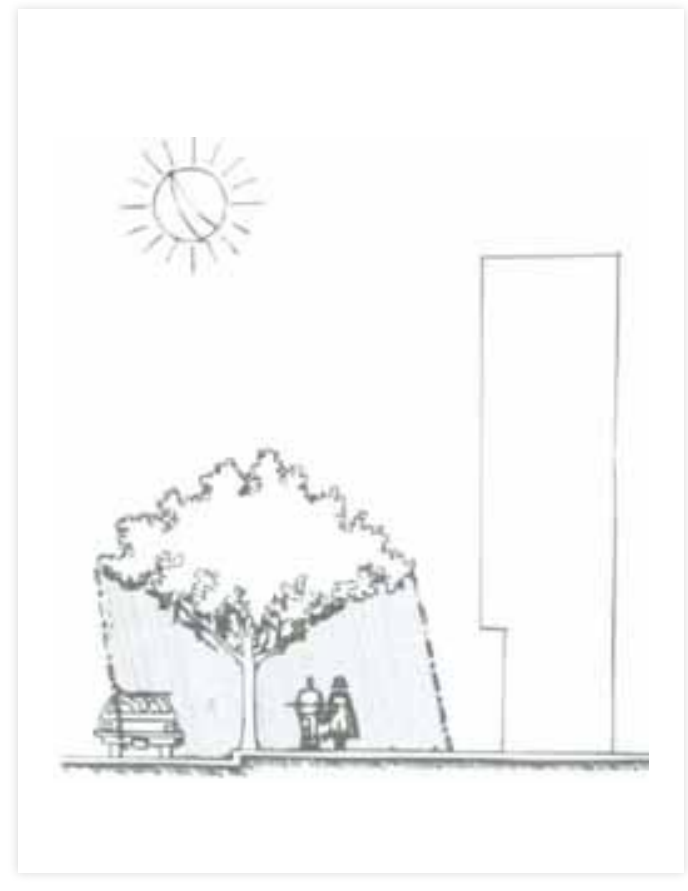

Figura 6: Calçadas mais largas viabilizam árvores e canteiros maiores, consequentemente mais sombra e permeabilidade. Fonte: Mascaró, 2010.

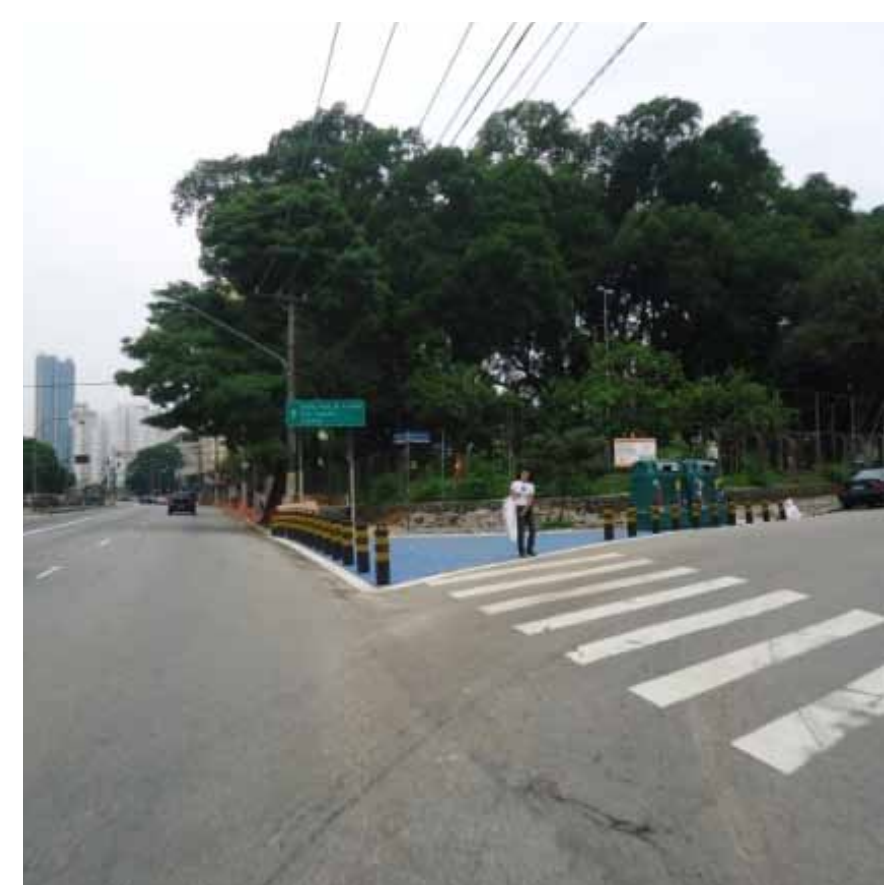

Foto 2: Praça Conde Francisco Matarazzo Junior, uma das poucas áreas públicas com arborização significativa e equipamento de lazer e conforto térmico. A praça ajuda a compor parte da Av. Francisco Matarazzo,cujo canteiro central não está mais arborizado, permitindo dar identidade a este trecho da avenida, com qualidade pelo aconchego do verde. Crédito: Neila Custódio.

\section{Aspectos da saúde humana}

A presença de áreas verdes na cidade influencia diretamente na psique e no bem-estar do ser humano. A própria cor verde é mais fácil de ser percebida e conforta os olhos, quando cansados, pois se encontra em uma posição no espectro visível de luz verde (faixa entre 400 a 700 $\mathrm{mm})$, que, quando projetada na retina, exige o mínimo de esforço muscular em relação às demais cores (pesquisa feita por Paula Shinsato. Curso Paisagismo Sustentável, 2012). Desta forma, podemos entender que, quanto mais verde tivermos, melhor para a saúde das pessoas e, consequentemente, a saúde da cidade. Neste aspecto, contemos não somente com as áreas livres públicas, mas também com a implantação de paredes verdes e tetos verdes. 

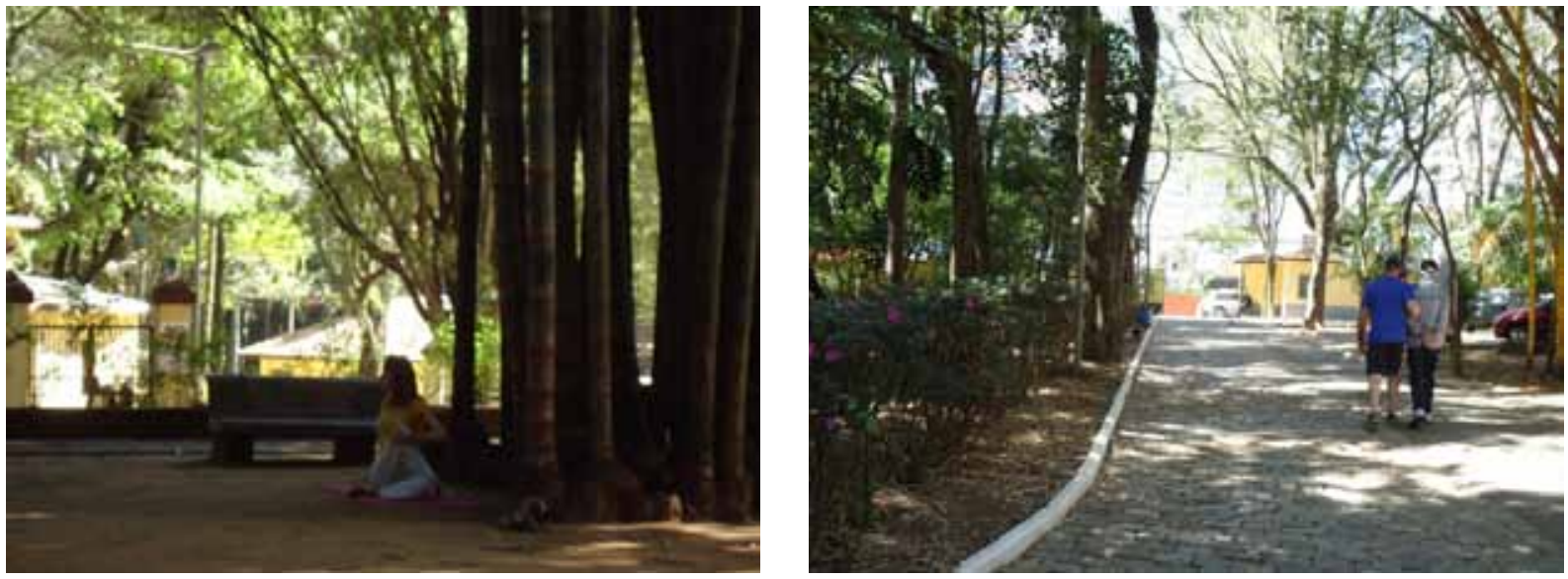

Fotos 3 e 4: Parque da Água Branca - área pública para descanso e lazer. O bambuzal em especial é direcionado às pessoas que praticam yoga, meditação, assim como o caminhar. Crédito: Neila Custódio.

\section{Aspectos econômicos}

Com relação aos aspectos econômicos, sabemos que um empreendimento tem seu valor aumentado, quando próximo a áreas verdes. Segundo a pesquisadora Paula Shinsato, nas cidades de Emmen, Appledoorm e Leiden, na Holanda, edifícios com vista para um parque aumentaram o valor dos apartamentos em $8 \%$, a proximidade com uma área verde valoriza a propriedade em $10 \%$, e com um espelho d'água valoriza a residência em $7 \%$. Por outro lado, a vista para outro edifício desvaloriza a propriedade em $7 \%$.

Foto 5: Av. Francisco Matarazzo cruzando com a Av. Pompeia. Novos empreendimentos de alto padrão, voltados para ruas áridas ou para os próprios edifícios. Apenas uma pequena parte da Av. Francisco Matarazzo, em frente ao Shopping Bourbon, está com o canteiro central arborizado. Crédito: Neila Custódio.

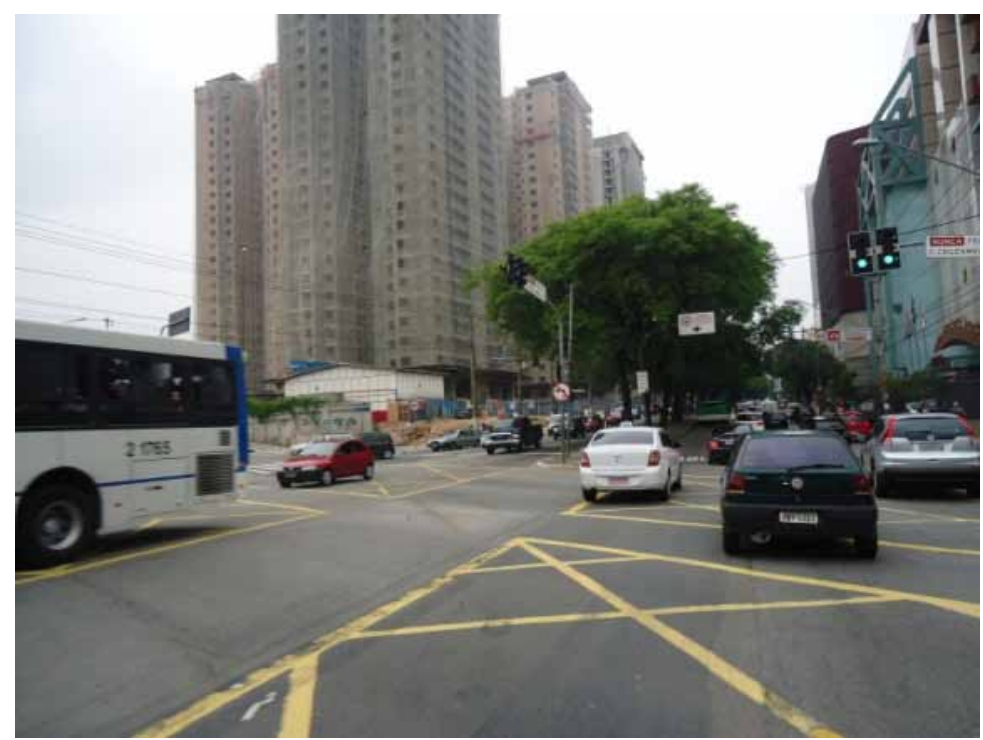




\section{COMPENSAÇÃO AMBIENTAL COMO MECANISMO PARA INFRAESTRUTURA VERDE - PLANTIO DE ÁRVORES}

Projetos arquitetônicos ambientalmente adequados levam a efeitos consistentes e, consequentemente, a benefícios para o meio urbano.

O plantio de árvores por compensação urbana tem diferenciações, se realizado em um sistema viário, ladeando um curso d'água, ou em logradouros, como praças, jardins e parques. Ele é efetivo quando associado a espaços livres que a ele dão suporte, e quando passa pela reflexão dos critérios da qualidade da paisagem, seja ela ambiental, estética ou funcional.

As compensações deveriam seguir projetos que incluam esses três critérios, para que não ocorra simplesmente a plantação de árvores para cumprir a obrigatoriedade de um TCA (Termo de Compromisso Ambiental). O uso inadequado da arborização, ou pela demanda do local, ou pelo mero cumprimento burocrático, pode atuar de forma a não contribuir com a melhoria ambiental e na qualidade da vida urbana.

A seguir, trataremos das hipóteses para o distrito da Barra Fundo, voltadas para a meIhoria da qualidade ambiental no que se refere ao microclima, com o plantio massivo de árvores. Desta forma, a eficácia dessa arborização deve ser tratada aqui como elemento indutor da qualidade ambiental, indo ao encontro das compensações ambientais, uma vez que as áreas permeáveis estão cedendo lugar a novos empreendimentos.

\section{HIPÓTESES PARA O DISTRITO DA BARRA FUNDA}

A partir da análise da região, percebemos que há possibilidades do incremento de vegetação, utilizando-se alterações dos perfis de algumas avenidas e ruas, para o plantio de arborização. Na área de estudo, a intenção é o incremento voltado para a quantidade de vegetação a ser plantada.

Entendemos que a quantidade de árvores inseridas em algumas ruas e avenidas, aliada à possibilidade de caminhos interligados por ciclovias e calçadas confortáveis para caminhadas, contribuirá significativamente para amenização do clima, hoje problemático na região. A inserção destes equipamentos, como meio de transporte e lazer, permite que a região adquira mobilidade urbana e acessibilidade a pontos importantes da área. 
As hipóteses levantadas são possíveis conexões por caminhos verdes, e abertura de áreas permeáveis mal aproveitadas, como de estacionamentos transformados em parques, como áreas núcleos próximas às áreas de interesse social.

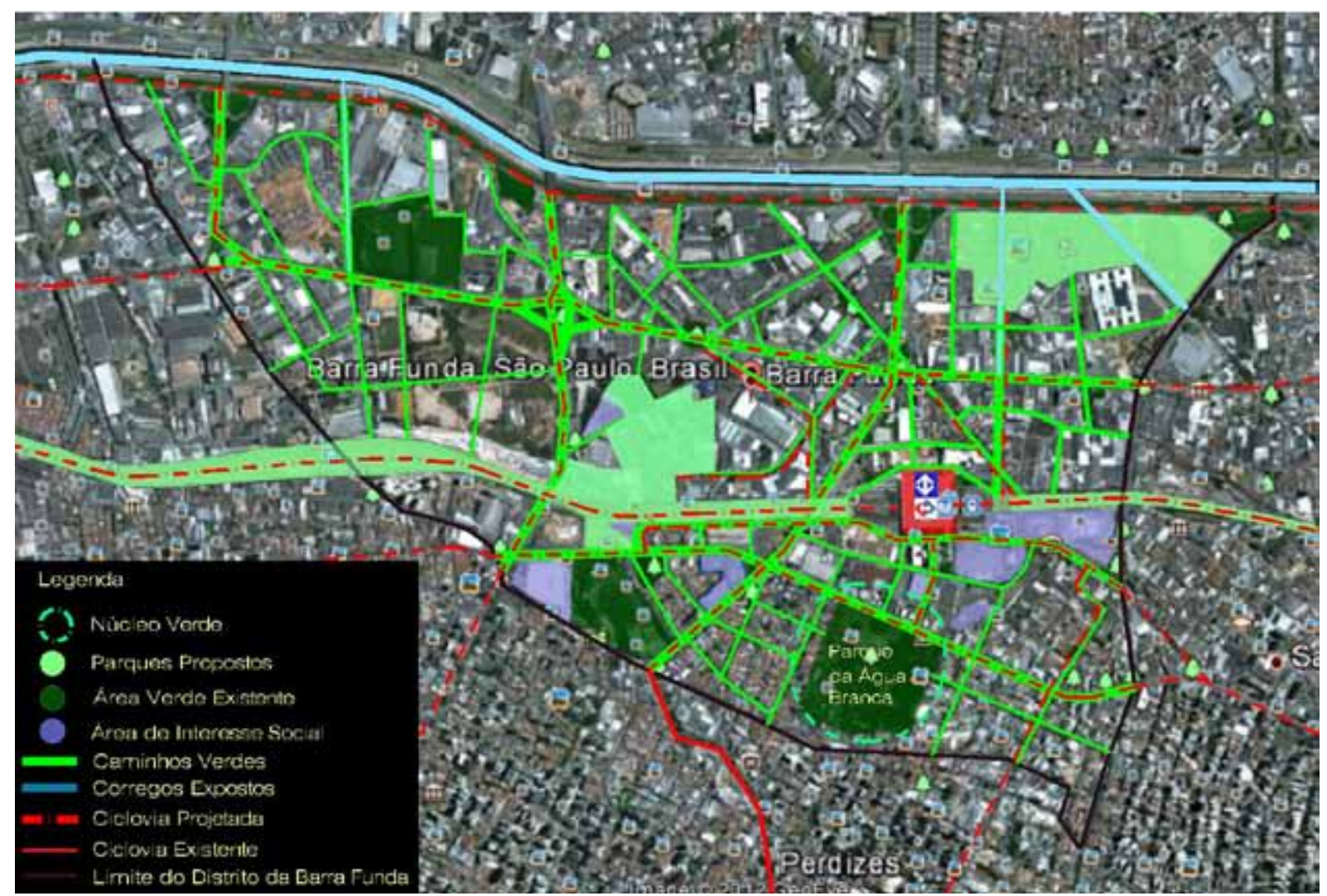

Mapa 2: Análise das hipóteses.

Para as ligações longitudinais, juntamente com a proposta do Parque Brás-Lapa, estão a Marginal do Tietê e a Avenida Marquês de São Vicente. Junto ao muro da CPTM, a Rua da Várzea, passando pelo Terminal da Barra Funda, junto à Unesp seguida pela da Rua Gustav Willi Borgoff, que se estenderia até a Rua Santa Marina, pela lateral da área férrea. No lado oposto, também junto ao muro da CPTM, a Av. Auro Soares de Moura Andrade, passando por trás da Casa das Caldeiras, estendendo-se até a Rua Santa Marina. Ainda a Rua Tagipuru, a Av. Francisco Matarazzo e a Rua Turiassu.

A alteração das tipologias dessas avenidas compreende especificamente a diminuição do leito carroçável e acréscimo da largura das calçadas e canteiros centrais, para abrigar ciclovia. Para as ruas não tão largas, aumentaríamos significativamente as calçadas, pondo arborização e canteiros pluviais, e um dos lados abrigaria a ciclovia. 
As ligações transversais são os viadutos Pacaembu, Antártica e Pompeia, que terão seu perfil alterado também, com a diminuição do leito carroçável, para um canteiro central que abrigue o caminhar seguro do pedestre e a ciclovia.

Ainda transversalmente, temos a Av. Thomas Edison, desde a Marginal até a Rua da Várzea, a Rua Prof. José Nelo Lorenzon, cortando o Nacional Clube até chegar à extensão da Rua Gustav Willi Borgof, e a Rua Quirino dos Santos, junto ao córrego de mesmo nome. Do lado oposto ao parque, teremos, iniciando a oeste, a Rua Joaquim Ferreira até a Rua Carlos Vicare, que intermedeia as avenidas longitudinais Santa Marina e Francisco Matarazzo, a Rua Dona Germaine Burchard, e a Rua Cardoso de Almeida com a Rua Turiassu.

As demais ruas apontadas no mapa seriam ruas arborizadas, podendo também ter alterada sua tipologia, sem abrigar efetivamente ciclovias.

A seguir, mostraremos algumas fotos das ruas apontadas acima, para as conexões transversais e longitudinais do distrito da Barra Funda.
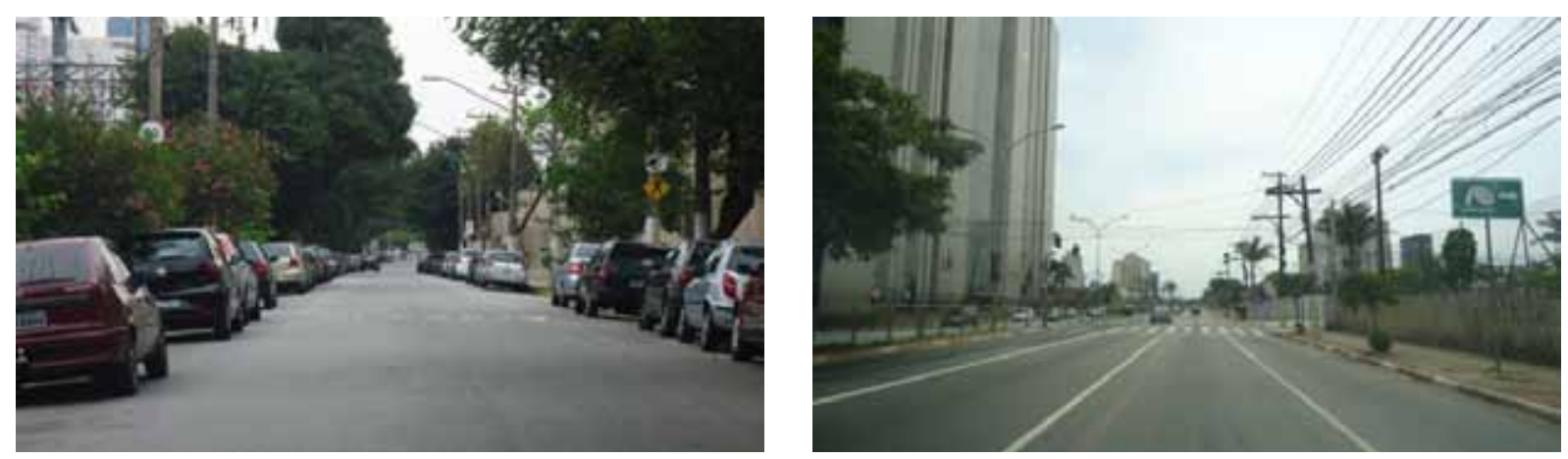

Fotos 6 e 7: Ligações longitudinais: Rua da Várzea, com 12 metros de largura, e Av. Marquês de São Vicente, com 36 metros de largura. Crédito: Neila Custódio.
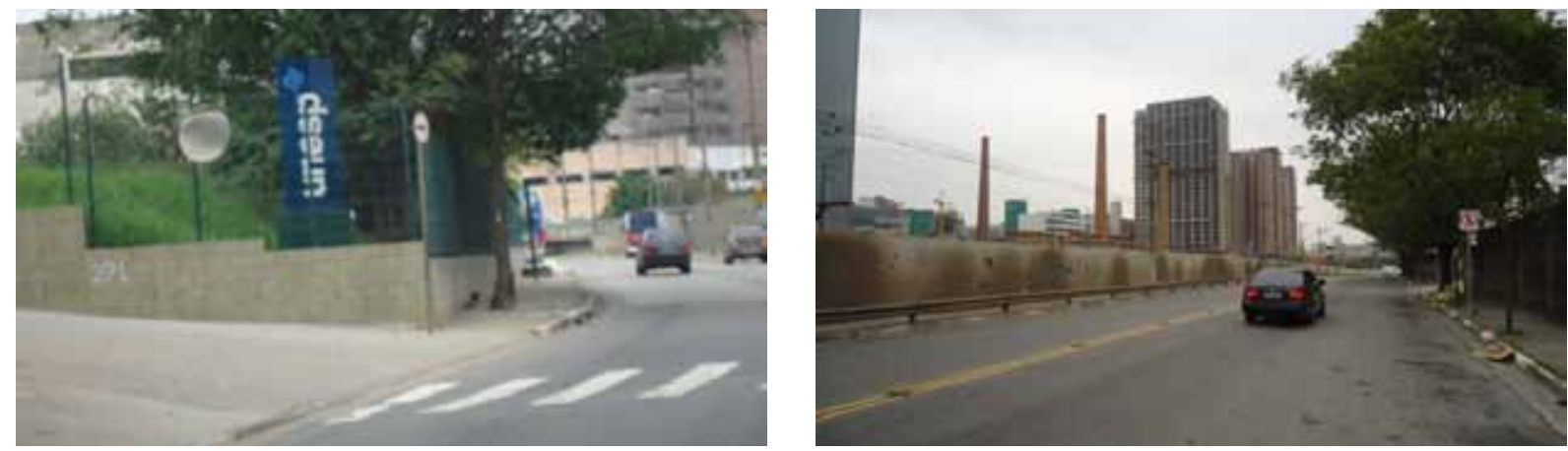

Fotos 8 e 9: Ligações longitudinais: Rua junto ao Terminal Barra Funda e a Rua Gustav Willi Borghoff, junto ao muro da CPTM - lado norte. Crédito: Neila Custódio. 

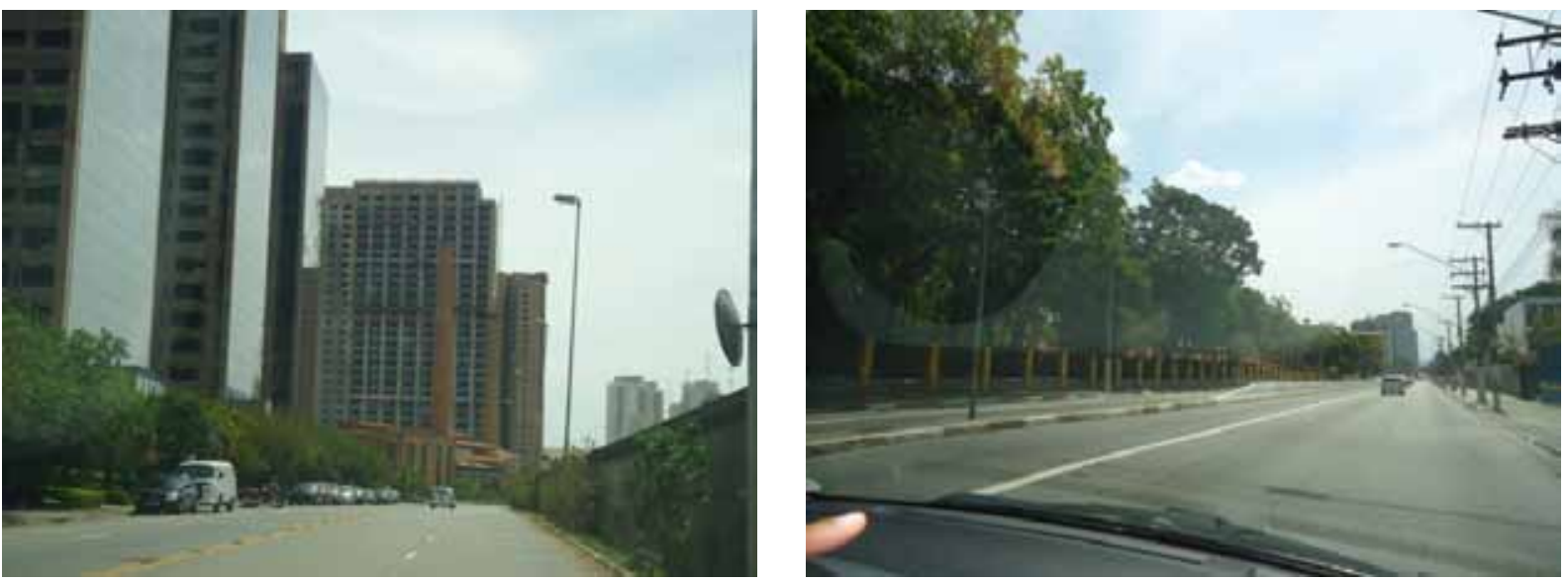

Fotos 10 e 11: Ligações longitudinais: Av. Auro Soares de Moura Andrade, junto ao muro da CPTM, ao su,l e Av. Francisco Matarazzo. Crédito: Neila Custódio.
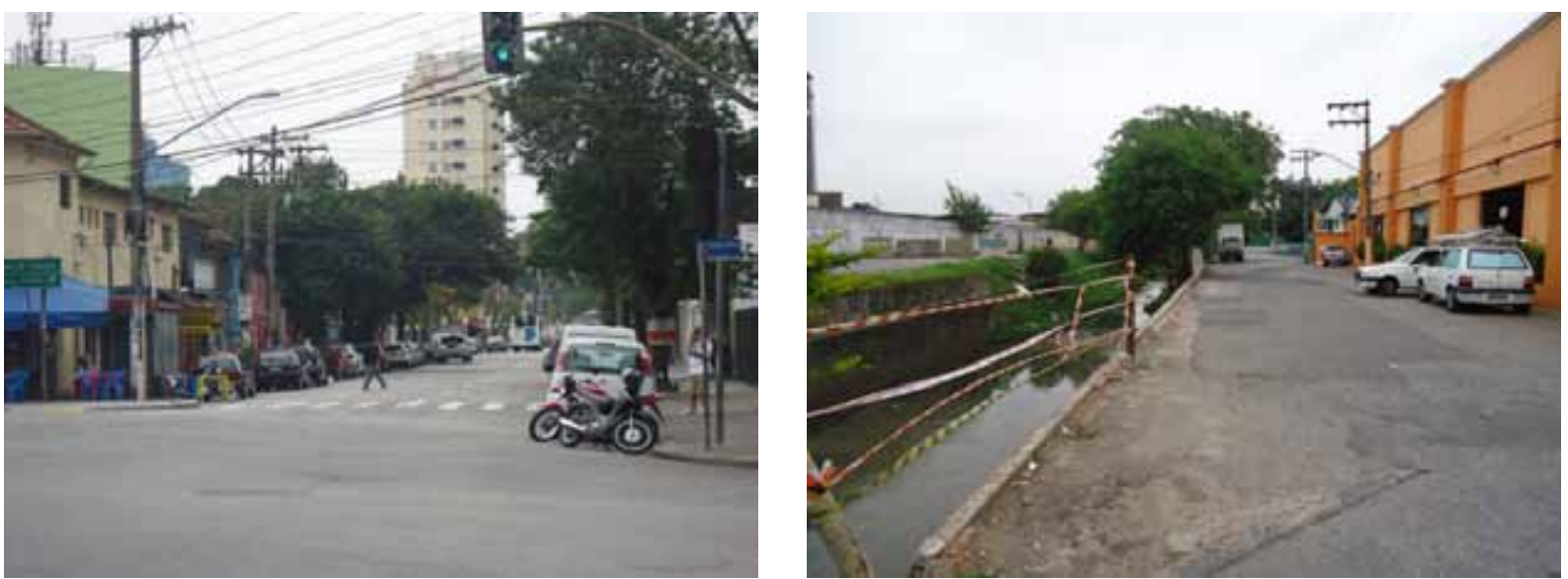

Fotos 12 e 13: Ligações transversais: Rua Quirino dos Santos, antes e depois da Av. Marquês de São Vicente. Crédito: Neila Custódio.
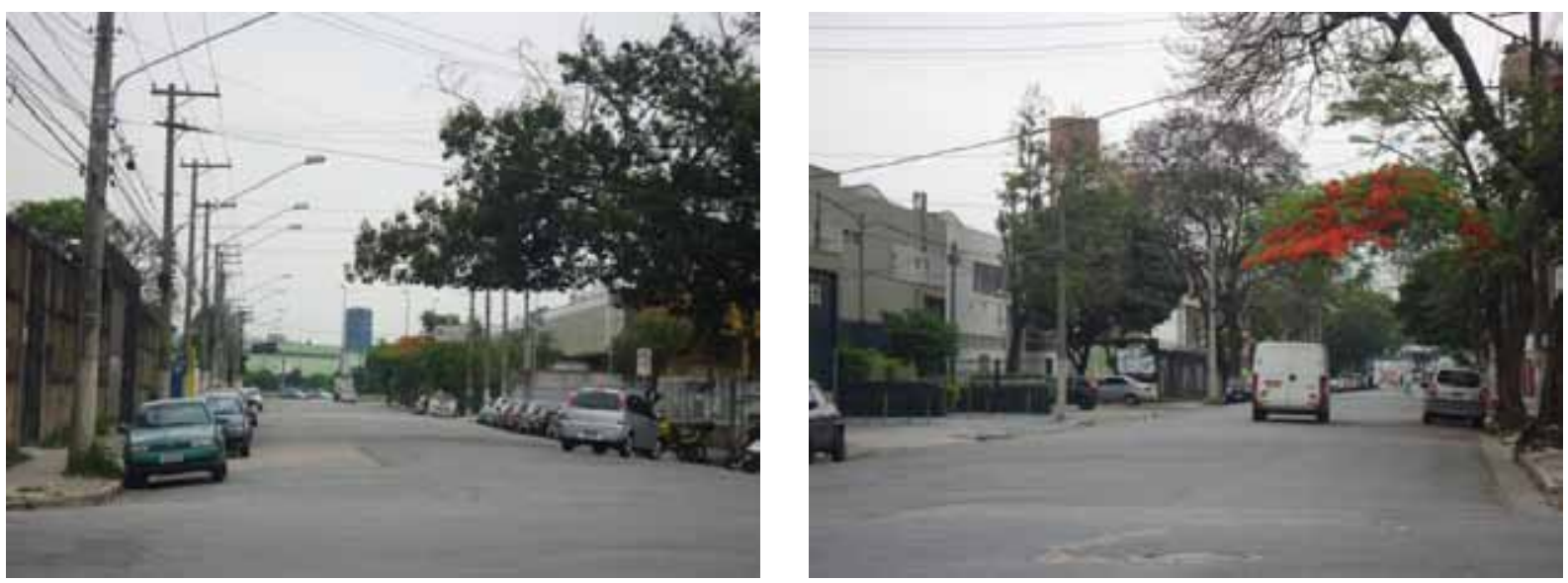

Fotos 14 e 15: Ligações transversais: Av. Thomas Edison, voltada para a Marginal do Tietê e voltada para o Terminal Barra Funda. Crédito: Neila Custódio. 

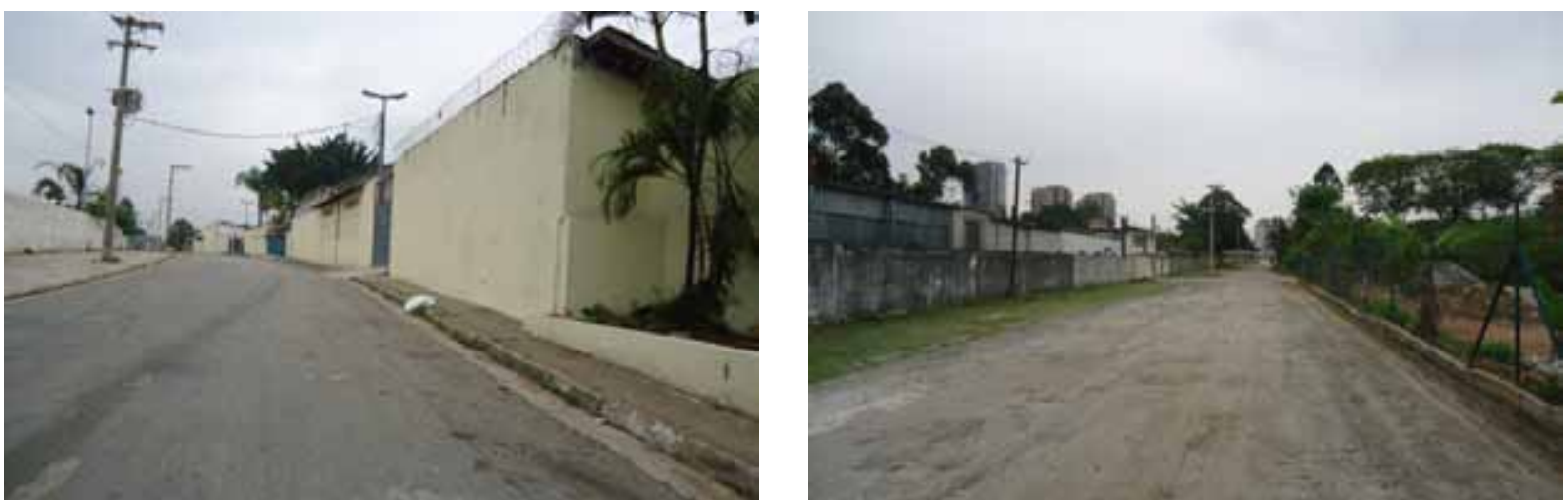

Fotos 16 e 17: Ligações transversais: Ruas sem saída, não formalizadas, que poderia ser rasgadas pelas grandes áreas de estacionamento próximas ao Viaduto Pompeia. Crédito: Neila Custódio.

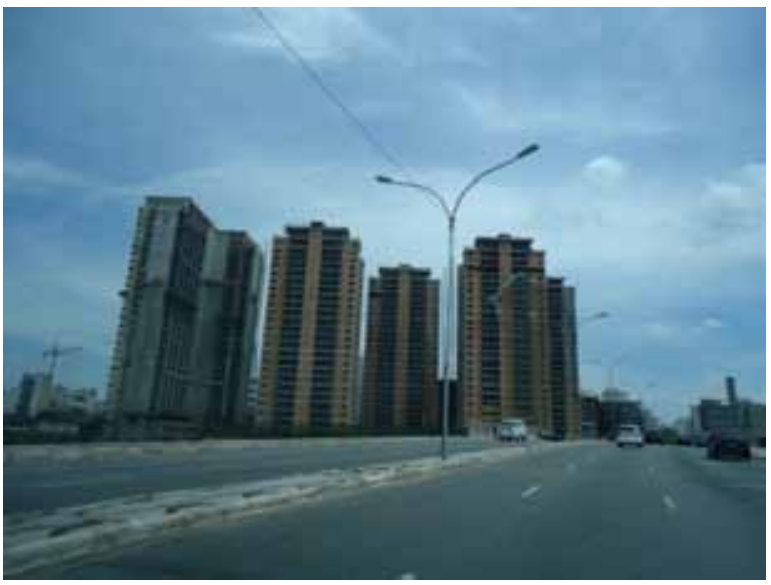

Fotos 18 e 19: Ligações transversais: Viaduto Pompeia e a curva da Av. Auro Soares de Moura Andrade, chegando à Av. Francisco Matarazzo, junto à Praça Conde Francisco Matarazzo Junior. Crédito: Neila Custódio.
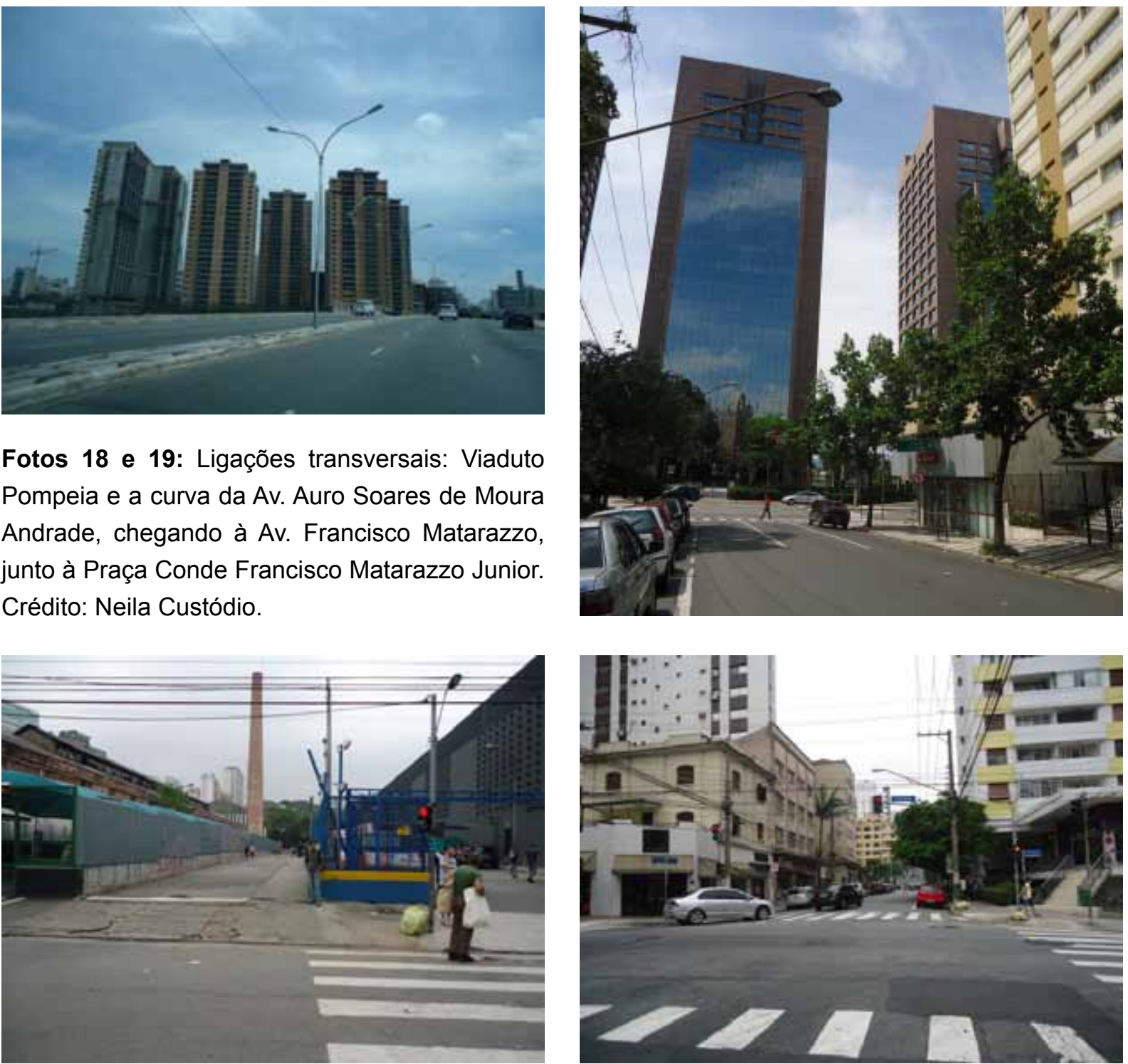

Fotos 20 e 21: Ligações transversais: viela a ser aberta entre a Rua Tagipuru e Av. Francisco Matarazzo. Crédito: Neila Custódio. 
A seguir, mostraremos algumas tipologias prováveis para as alterações das avenidas e ruas, com a finalidade de proporcionar acessibilidade e mobilidade às pessoas.

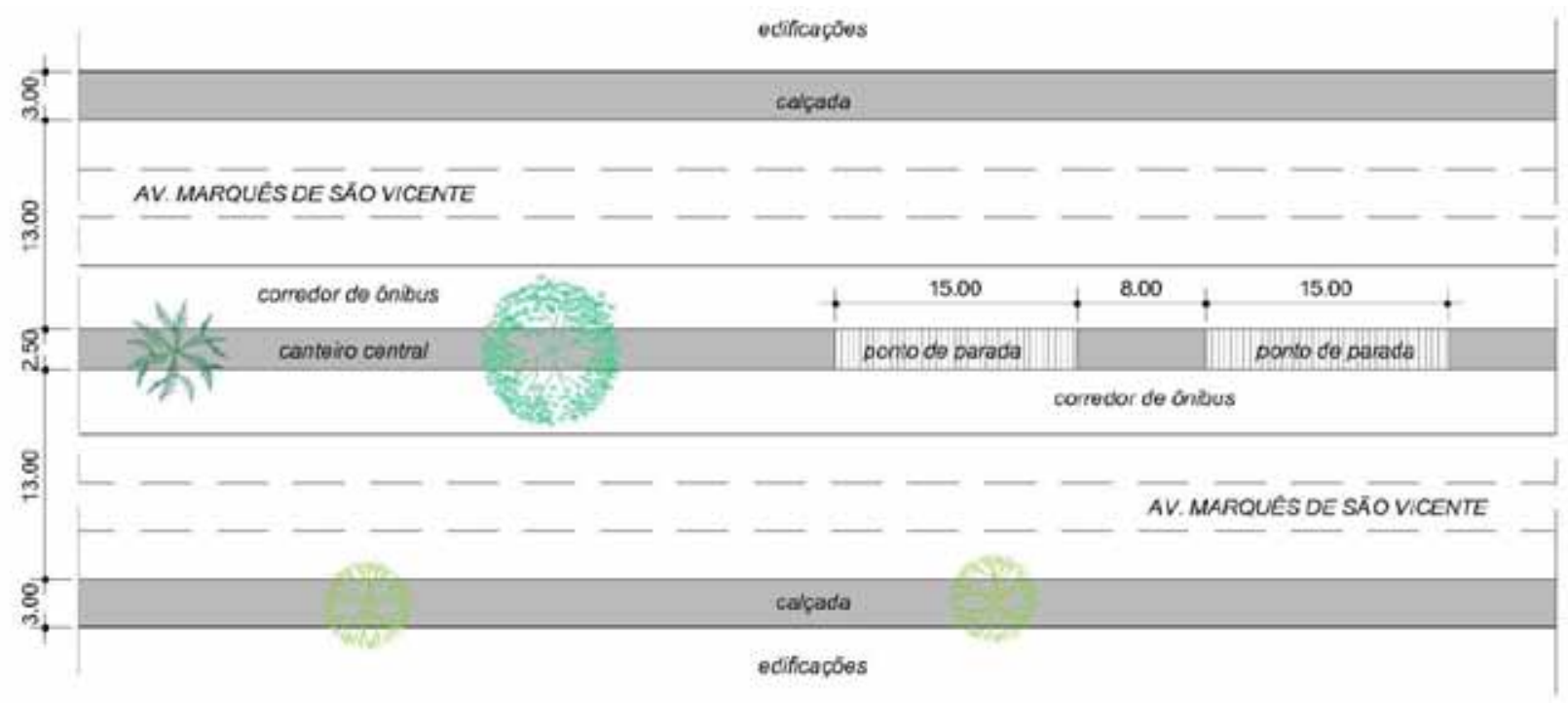

PLANTA - situação atual

ESC. 1:500

Figura 7: Nesta planta, podemos perceber a escassez de arborização, resultando em uma área árida, e principalmente a priorização dos automóveis, em detrimento dos pedestres. Crédito: Neila Custódio.

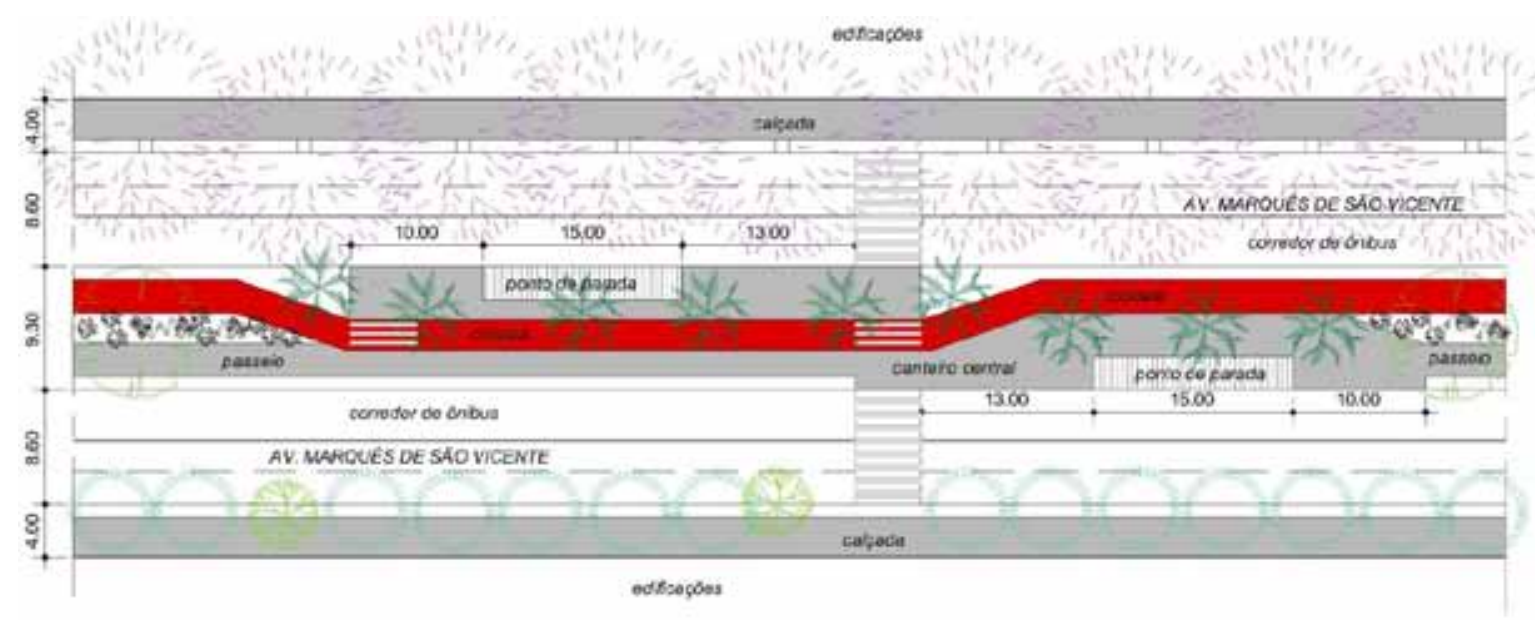

PLANTA - situação pretendida ESC. 1500

Figura 8: Nesta planta, mostramos como é viável a melhoria da Av. Marquês de São Vicente, com a proposta de alargamento das calçadas e canteiro central com ciclovia, arborização e canteiros verdes, que funcionariam como jardins de chuvas. Crédito: Neila Custódio. 


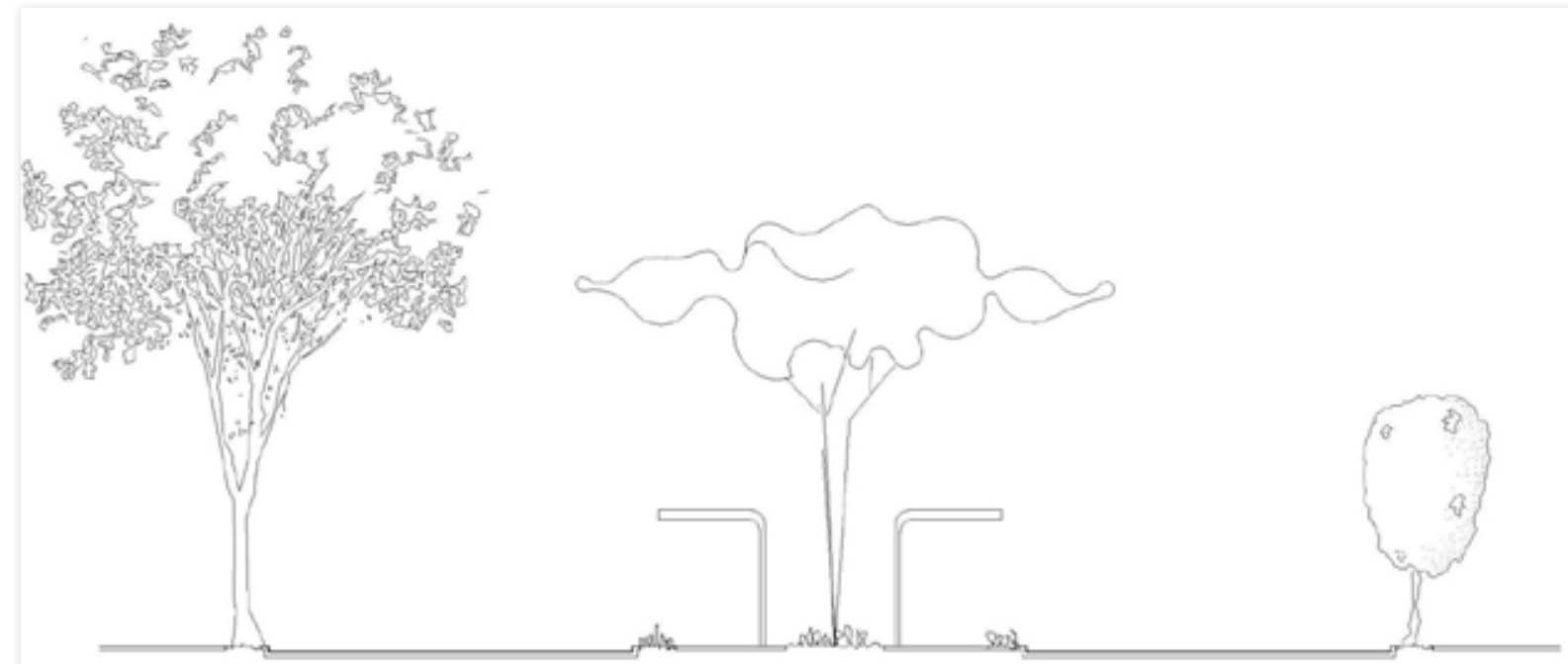

\section{CORTE TÍPICO - Situação pretendida}

ESC. SEE

Figura 9: Neste corte, mostramos especialmente a estruturação da arborização em portes pequeno, médio e grande, e a forma da copa mais aberta na lateral esquerda, ou mais centralizada no canteiro, para que o ônibus não faça a poda, ou mais colunar, para não atrapalhar a fiação elétrica. Crédito: Neila Custódio.

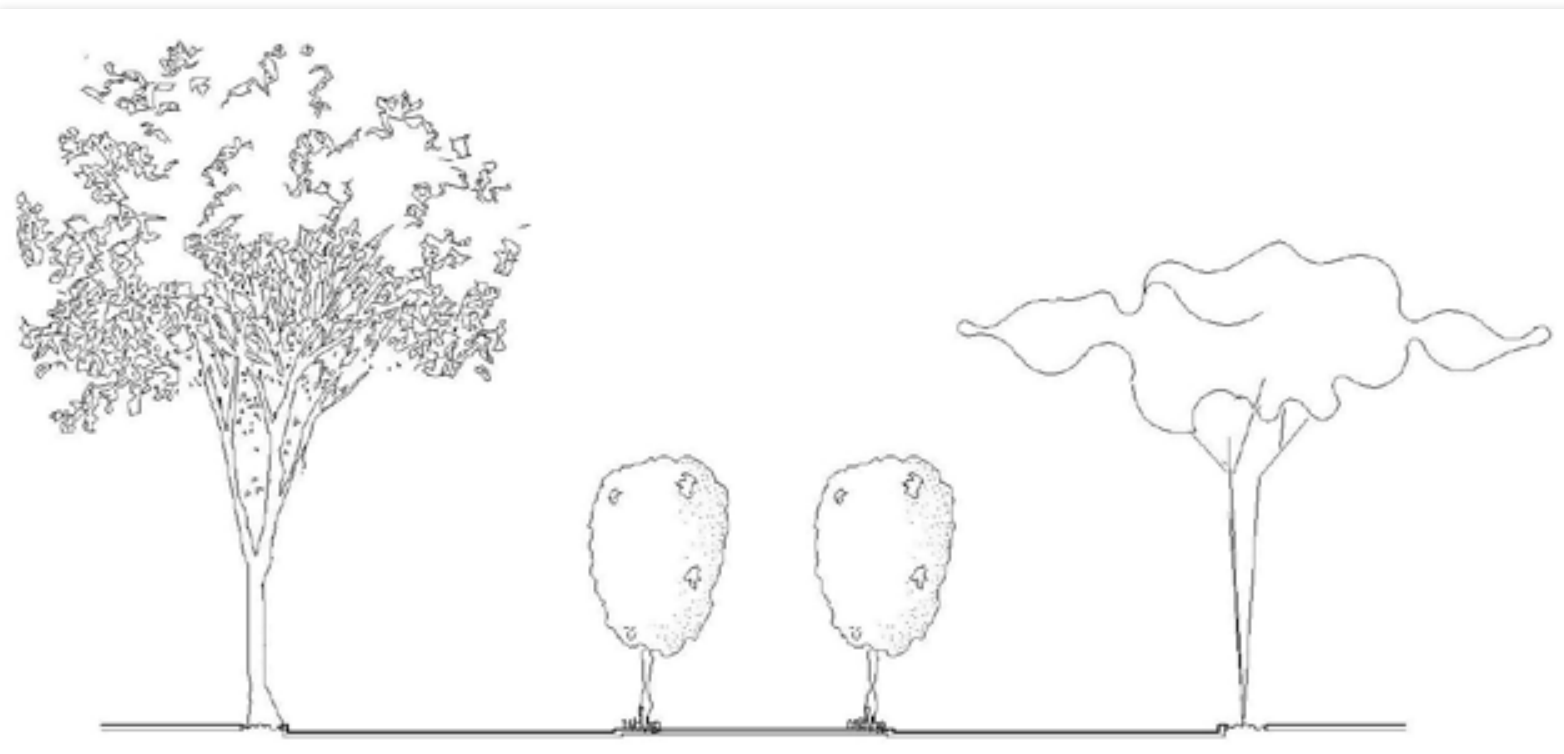

\section{CORTE TÍPICO - Ruas largas que podem abrigar ciclovia}

ESC. S/E

Figura 10: Neste corte, vemos especialmente a estruturação da arborização em portes pequenos no canteiro central, para abrigar a ciclovia, e nas laterais, onde não há fiação elétrica, as de grande porte, e as de médio e pequeno onde há fiação. Crédito: Neila Custódio. 


\section{CONSIDERAÇÕES FINAIS}

A análise da área de estudo denominada distrito da Barra Funda indica que a região apresenta uma necessidade extrema de novas áreas verdes e arborização viária, já que nela só existe o Parque da Água Branca como núcleo verde, e as ruas são pouco ou nada arborizadas. A utilização da vegetação procura reduzir os efeitos de ilha de calor e da poluição urbana. Desta forma, as diretrizes aqui traçadas para arborizar a região, seguindo os critérios da infraestrutura verde integrada à cidade, resulta em aberturas de áreas verdes permeáveis, como novos parques formando núcleos verdes, massiva arborização nas ruas formando caminhos verdes, e a criação do Parque Linear Brás-Lapa, que seria o elo dessa nova malha verde. Estas novas áreas e ruas seriam também utilizadas para a acessibilidade e mobilidade urbana, com a implantação de ciclovias e valorizando o "andar a pé", formando uma trama de conexões.

A arborização viária de ruas e avenidas se torna aplicável, de acordo com nosso estudo sobre a região, quando observamos suas configurações, sendo estas de grandes dimensões, com muitas faixas, possibilitando o alargamento dos canteiros centrais para a implantação de ciclovias, caminhos de pedestres e plantação de árvores, assim como o alargamento e plantio de árvores nos passeios. Essas ruas e avenidas seriam conectadas com o metrô e o trem, formando uma rede de mobilidade urbana de baixo carbono. A área também apresenta grandes áreas ociosas, aptas a abrigar parques formando áreas núcleos. Portanto a ligação dos fragmentos e núcleos verdes, aliada à arborização de áreas ociosas e a implantação de ciclovia, será de grande valia do ponto de vista ecológico, térmico e social, além de valorizar a região.

Entendemos que, para que haja esse plano de arborização, há necessidade de que as políticas públicas estejam voltadas de fato para a questão ambiental, com um plano diretor de arborização, políticas de manutenção, educação e conscientização da população.

\section{REFERÊNCIAS BIBLIOGRÁFICAS}

CATUZZO, Humberto. Ilhas de Calor/Microclima-Telhados Verdes: Possibilidade de redução da llha de Calor na metrópole de São Paulo. In: XII Simpósio Nacional de Geografia Urbana, 2012, Belo Horizonte. Anais do XII SIMPURB, 2011. 
COELHO, Leonardo Loyolla. A contribuição das compensações ambientais para a construção de um sistema de espaços livres públicos livres na cidade de São Paulo. Revista Paisagem e Ambiente - Ensaios, São Paulo, n. 26, 2004.

Compensação ambiental: Uma alternativa para a viabilização de espaços livres públicos para lazer e convívio na cidade de São Paulo. Dissertação de mestrado - FAUUSP. São Paulo, 2008.

MASCARÓ, Lucia e Juan. Vegetação Urbana. 3 ed. Porto Alegre: Editora 4, 2010. Revista LabVerde. Infraestrutura verde em São Paulo: O caso do corredor verde Ibirapuera-Villa Lobos. São Paulo, n.1, p. 134-154, 2010.

Revista LabVerde. Infraestrutura verde: Sustentabilidade e resiliência para a paisagem urbana. São Paulo, n.1, p. 91-112, 2010.

SHINSATO, Paula. Curso Paisagismo Sustentável: Estratégias de Integração no Projeto de Edifícios e Cidades Sustentáveis - dias 18 e 19 de outubro de 2012, no Espaço Vista Paulista - São Paulo.

SÃO PAULO (Município). Secretaria Municipal de Planejamento Urbano/Secretaria Municipal do Verde e Meio Ambiente. Atlas ambiental do município de São Paulo, São Paulo, 2007.

. Secretaria Municipal de Planejamento Urbano. Plano Diretor Estratégico. Lei n. 13.430 de 13 de setembro de 2002. São Paulo, 2002.

SÃO PAULO (Estado). Secretaria do Meio Ambiente/Secretaria Municipal de Planejamento. Vegetação significativa do município de São Paulo. São Paulo, 1988.

\section{Sites pesquisados:}

http://www.suapesquisa.com/o_que_e/ilha_de_calor.htm http://www.revistalabverde.fau.usp.br/edicoes.html 